\title{
Evaluating sustainability performance in supply chain management: an empirical research of Vietnam producers' coordinates suppliers
}

\author{
Van Phuoc Nguyen
}

Received: 30 June 2019 / Accepted: 11 June 2020

\begin{abstract}
Our research dissects the adequacy of sustainability performance in supply chain management (i.e., evaluation and coordinated effort). Based on survey result from 96 Vietnam producers, the paper determines the effect that the two practices have on the producer company's and the provider's social performances. SmartPLS was utilized to test the hypothesized connections among practices and execution. Our outcomes propose that while surveying providers adds to improve the purchasing company's social execution, teaming up with them upgrades the providers' social execution. However, the paper gives some extra of knowledge on the most proficient method to evaluate sustainability performance.
\end{abstract}

Keywords Sustainable supply chains · coordinated effort · Vietnam producers' - social responsibility performance

\section{INTRODUCTION}

In the present worldwide context, companies are constrained by governments, non-administrative associations and customers to act in a feasible way. In the quest for maintainability one key test they face is its expansion to other supply chain accomplices, for example, providers. Customers and other stakeholders do not differentiate between all the different actors in a supply chain (Seuring et al., 2013) and therefore, producers take the responsibility for their suppliers in front of stakeholders (Hartmann and Moeller, 2014; Koplin et al., 2007). (KRAUSE et al., 2009) emphasized this fact when stating that a firm is no more sustainable than its suppliers. In fact, a producer's sustainability performance can be damaged by their suppliers acting unethically. This is also true for the case of the social dimension of sustainability.

When a producer encounters shortcomings in their suppliers' sustainability performance it has the following options: (1) invest resources to increase its suppliers' performance or (2) search for alternative suppliers (Krause et al., 2000). This paper is based on the premise that the producer has chosen to improve its supplier sustainability performance through performs such as supplier evaluation and coordinated effort. Several authors have considered these two types of supply management performs to extend sustainability issues to suppliers (Gualandris and

\footnotetext{
Van Phuoc Nguyen

Department of International Business Administration, Ho Chi Minh City University of Foreign Languages Information Technology, 155 Su Van Hanh Street, Ward 13, District 10, Ho Chi Minh City

E-mail: nguyenvanphuoc@huflit.edu.vn
} 
Kalchschmidt, 2014; Lee and Klassen, 2008; Vachon and Klassen, 2006; Gavronski et al., 2011). While supplier evaluation entails the use of arm's length transactions by the producer, such as the evaluation of suppliers' sustainability performance; coordinated effort with suppliers comprises the producer's direct efforts and in volvement to jointly improve suppliers' sustainability performance (Gavronski et al., 2011; Gualandris and Kalchschmidt, 2014; Lee and Klassen, 2008; Vachon and Klassen, 2006). It is important to mention that although companies may use a hybrid structure comprising a mix of both performs (Williamson, 1991), in this paper we will follow previous literature on the extension of sustainability to suppliers and focus exclusively on these two (i.e., supplier evaluation and coordinated effort with suppliers).

There is a major stream of the literature that has dissected the effect of these performs on execution. In any case, the majority of these papers have concentrated for the most part on the environmental measurement (Green etal., 2012; Leeand Klassen, 2008; Theyel, 2001; Vachon and Klassen, 2008; Zhu and Sarkis, 2007) being constrained the literature on the social one (Foerstl et al., 2010; Hollos et al., 2012) however no exploration has considered the effect of assessment and composed exertion on both the provider and the producer's social execution. Additional, the present status of examination around there would appear to give just a fractional perspective on the viability of these.

Considering the previously mentioned gaps, our goal is to investigate the adequacy of both evaluation and facilitated exertion on accomplishing social sustainability along the supply chain by breaking down the impact of these performs on both the producer's and the provider's social execution. All the more explicitly, our examination expects to respond to the accompanying exploration question: Are these perform adding to improve providers' or potentially producer' social execution? To respond to our research question we expound a conceptual model and place a lot of research hypotheses that relate each type of perform to the providers' and producer's social execution. At that point, we depend on information originating from 96 Vietnamese producers' and use Partial Least Squares (PLS) to test research model.

This research challenges and extend ongoing work on the appropriation of provider evaluation and coordinated effort to achieve sustainability along the supply chain by analyzing a disregarded area of sustainability - the social measurement - and by thinking about the providers' responsibility. We contend that the appropriation of the providers' point of view accentuates the pertinence of this examination. The augmentation of maintainability to providers involves two substances: the producer and the provider. By considering the producer execution as well as the provider's presentation we will expand the understanding we have about the connection between these flexibly the board performs and execution. We will have the option to explore if maker depend on these perform to improve their providers' maintainability execution or on the off chance that they actualize them basically as a way to improve their own sustainability execution. These outcomes will control organizations in their work to stretch out sustainability to different accomplices, for example, providers and as a result, acquire a genuinely sustainable supply chain by truly improving the providers' social execution.

\section{LITERATURE REVIEW}

\subsection{SUSTAINABILITY SUPPLY CHAINS: THE SOCIAL DIMENSION}

Sustainability has been defined as encompassing economic, environmental and social dimensions (Elkington, 1994). However, recent studies on the topic of sustainable supply management highlight the imbalance between the number of papers focusing on environmental and social issues (Ashby et al., 2012; Hollos et al., 2012; Leppelt et al., 2013). With the exceptions of (Carter 
and Jennings, 2004), one of the first papers analyzing social purchasing, and (Awaysheh and Klassen, 2010) who focused on the social dimension of sustainability, research on social issues in supply management has been scarce.

Social sustainability is met when companies support the preservation and creation of skills and capabilities of current and future generations, and promote health, support and equal and democratic treatment within and outside its borders (Mckenzie, 2004). Social sustainability encompasses two types of communities: internal (e.g., employees) and external (e.g., local communities with weak economic ties) (Pullman et al., 2009). In other words, companies need to care about the well-being of their employees and that of the local community in which it is embedded.

The difficulty to quantify social performance in comparison to the economic and the environmental performance dimensions makes it the most neglected element of the triple bottom line (Mckenzie, 2004). The lack of studies that have looked at the social performance dimension of sustainability results in a lack of agreement with respect to the measurement of this construct (Giovanni, 2012). For instance, some papers have considered employees' working conditions (Giovanni, 2012) while others have used social reputation to measure social performance (Gimenez et al., 2012).

Recently, (Golini et al., 2014) and (Gualandris et al., 2014) measured social performance considering items related to both employees working conditions and social reputation. It is also important to highlight that all these previous authors have considered the social performance of the producer and not the social performance of the supplier in their studies. Employees working conditions covers "a broad range of topics and issues, from working time (hours of work, rest periods, and work schedules) to remuneration, as well as the physical conditions and mental demands that exist in the workplace" (Ilo, 2014). Corporate reputation, on the other hand, is a more intangible concept. It is the result of the process of "social legitimization" of the firm (de Castro et al., 2006). Martin de Castro et al. (2006) carried out an empirical research to measure this "socially complex" factor and concluded that corporate reputation is made up of two dimensions: (1) business reputation and (2) social reputation. Business reputation includes the different aspects related to the agents and stakeholders closely tied to the business activities of the firm, such as customers, suppliers, managers or employees. Social reputation is related to the insights and perceptions of stakeholders not so close to the day-by-day business activities, such as investors and the community in a wider sense (de Castro et al., 2006).

In fact, as pointed out by (KRAUSE et al., 2009) a company is no more sustainable than its suppliers, meaning that producer need to implement performs that allow them to extend social responsibility to suppliers. Our research will analyze on performs aimed at improving the wellbeing of suppliers' employees. The reason why we have focused on performs aimed at improving employees' working conditions at the suppliers' premises and not on other performs that exclusively look at the suppliers' local communities is the following: the most challenging sustainable issue that producer face is related to the poor working conditions existing in many suppliers' plants. Other papers in the supply chain management field have also followed a similar approach and have focused on performs aimed at the well-being of employees (Awaysheh and Klassen, 2010; Pagell and Gobeli, 2009).

In other words, one of the objectives of sustainable supply management performs should be the improvement of the suppliers' social performance. In that sense, when researching the impact of sustainable supply management practices on performance, it is worth to include the suppliers' social performance. For this reason, in this paper we consider the suppliers' social performance and measure it in terms of their employees' working conditions. 


\subsection{EXTENDING SOCIAL ISSUES TO SUPPLIERS: EVALUATION AND COORDINATED EFFORT}

To effectively extend sustainability to its supply base a producer can adopt sustainable supply management, which entails the integration of sustainable considerations into supplier selection, evaluation and coordinated effort (Gavronski et al., 2011). This paper is based on the premise that the producer has chosen to improve its supplier sustainability performance through performs such as supplier evaluation and coordinated effort. Other studies have followed a similar approach (Gualandris and Kalchschmidt, 2014; Lee and Klassen, 2008; Vachon and Klassen, 2006).

Supplier evaluation entails arm's length transactions performed by the producer and is generally concerned with controlling suppliers' outputs with respect to specific performance criteria (i.e., social performance) (Gavronski et al., 2011; Gualandris and Kalchschmidt, 2014; Lee and Klassen, 2008; Vachon and Klassen, 2006). In this case, the adoption of evaluation performs implies the evaluation and control of suppliers with respect to social issues (i.e., working conditions, use of child labor, compliance with human rights). It includes in-depth evaluations of the suppliers' social performance (Krause et al., 2000) and can take the form of questionnaires, non-regulatory standards or audits (Min and Galle, 1997; Walton et al., 1998). The evaluation process, allows the producer to determine if the supplier meets current and future business needs. The producer needs to quantify and communicate the results of the evaluation to suppliers so that they are aware of the possible discrepancies between their current performance and the producer expectations (Prahinski and Benton, 2004). This way, suppliers are given directions for improvement (Krause et al., 2000).

Coordinated effort with suppliers is based on the cooperation between a buyer and a supplier and aims to jointly improve performance (Gavronski et al., 2011; Gualandris and Kalchschmidt, 2014; Lee and Klassen, 2008; Vachon and Klassen, 2006). These buyer-supplier interactions include: producer investments in the supplier through training and education of suppliers' personnel, dedicating producer personnel temporarily to the supplier, sponsoring meetings for suppliers in order to share information and know how, and undertaking joint applied research (Corbett and Klassen, 2006; Lee and Klassen, 2008; Vachon and Klassen, 2008).

Several authors have provided support for the relationship between sup- plier evaluation and coordinated effort with suppliers (Foerstl et al., 2010; Krause et al., 2000). Supplier evaluation enables companies to identify where suppliers need to be developed (Hahn et al., 1990). Once the areas of improvement have been identified, producers can focus their resources to help suppliers to obtain the required capabilities. (Foerstl et al., 2010), after conducting a multiple case research, point out that supplier evaluation regarding sustainability issues enables the implementation of supplier development initiatives such as training. Similarly, (Gimenez and Sierra, 2013) found that before assisting suppliers in sustainability issues companies should assess them and identify those areas that require development. Thus, based on these arguments we hypothesize that:

Hypothesis 1. Supplier evaluation is positively related to coordinated effort with suppliers

\subsection{SUPPLIER EVALUATION, COORDINATED EFFORT WITH SUPPLIERS AND SOCIAL PERFORMANCE}

Following (Seuring and Müller, 2008) suggestion to conduct more research built on strong theoretical backgrounds, we adopt the lenses of the Transaction Cost Theory (TCT) and the Resource Based View (RBV). In addition, the lack of previous empirical studies on the impact of these performs on the social dimension of both producers and suppliers' performance also 
highlights the need to rely on sound theoretical paradigms. On the one hand, we will use TCT to develop the evaluation - performance hypotheses. In a buyer-supplier relationship there is a risk that suppliers behave opportunistically. That is, with a lack of candor or honesty in transactions, to include self- interest seeking with guile" (Williamson, 1975) (e.g., employ child labor to reduce costs). Next to, the RBV will provide reasons why coordinated effort is suitable to manage buyersupplier relationships although leading to an increase on transaction costs.

\subsection{SUPPLIERS EVALUATION AND SOCIAL RESPONSIBILITY PERFORMANCE}

In a buyer-supplier relationship, the risk of suppliers acting opportunistically is present. Opportunistic behavior implies that suppliers exhibit "self-interest with guile" (Williamson, 1981). Suppliers can behave dishonestly when it comes to the management of sustainability. These types of behaviors are what we consider opportunistic behaviors as they are used by suppliers to achieve lower costs knowing that these perform are not accepted by producers. Suppliers may make use of these performs due to the presence of information asymmetries: producers do not have a direct control over the working conditions in the suppliers' premises. To prevent their suppliers from acting unethically, producers can implement supplier evaluation performs, which entail costly monitoring and evaluative programs (Carter and Rogers, 2008; Simpson and Power, 2005). The implementation of these types of performs by the producer will lead to a reduction/cease on the opportunistic behavior of the supplier due to the pressure of being evaluated and controlled. If opportunistic behavior is reduced (i.e., they stop using child labor, they do not force their employees to work an excessive number of hours, etc.) the social sustainability of the supplier will be improved (Carter and Rogers, 2008). In fact, as pointed out by Lee and Klassen (2008) suppliers' environmental evaluation pressures them to start considering environmental factors in their own supply chains. This mechanism exerts coercive pressure on the supplier. We believe this pressure will push suppliers to comply not only with environmental but also with social issues. Based on the above studies, we expect the evaluation of suppliers by the producer to exert pressure on the supplier and hence reduce their opportunistic behavior regarding social issues, leading to an increase in their social performance (i.e. compliance with human rights, child labor employment, etc.). In that sense, we hypothesize that:

Hypothesis 2. Supplier evaluation improves the suppliers' social performance

In the literature, there is evidence for the positive and direct relationship between suppliers' evaluation and monitoring and the producer's sustainability performance (Foerstl et al., 2010; PAGELL and WU, 2009; Spence and Bourlakis, 2009). For instance, assessing suppliers with respect to sustainability issues allows the producer to avoid reputation damage (Foerstl et al., 2010) and hence improve its performance. According to (Handfield et al., 2005) companies possessing a formal monitoring system on corporate social responsibility in their supply chains will experience performance advantages. Recently, (Gualandris et al., 2014) found that the implementation of sustainable supply management performs (which included monitoring of corporate social responsibility performs) lead to improvements in the sustainability performance of producers (measured as reputation and employees' satisfaction). In line with these authors, we expect that the evaluation of suppliers in terms of social issues leads to a better producer's social performance. By implementing evaluation performs, producers will be able to evaluate their suppliers' performance in terms of social issues, avoiding reputation risk and showing that their supply chain is socially responsible. Similarly, we can expect that the evaluation of the working conditions at the suppliers' premises will lead to more satisfied workers in the producer as they will feel they are working in a more sustainability oriented firm. Thus, based on the previous arguments we hypothesize that: 
Hypothesis 3. Supplier evaluation improves the producer's social performance

\subsection{COORDINATED EFFORT WITH SUPPLIERS AND SOCIAL PERFORMANCE}

According to the RBV, coordinated effort enables the partnering companies (buyer and supplier) to build a set of valuable, rare and difficult to copy resources that lead to competitive advantage (Barney, 1991). As Carter and Rogers (2008), we consider as valuable, rare and difficult to copy resources the intangible resources such as the learning that occurs between buyers and suppliers when they are working together to improve sustainability. Webelieve this environmental focus can be extended to include also the social dimension of sustainability. That is, through coordinated effort, better social results can be achieved. The coordinated effort between a buyer and a supplier entails training sessions as well as joint work with respect to social issues, which will result in increased knowledge for both parties. This knowledge will allow both companies to develop specific capabilities to improve their own social performance (e.g., implementation of safety measures to avoid accidents). (Gold et al., 2009) strengthen the key role of coordinated effort in achieving sustainability goals. In the same line, (Klassen et al., 2005) emphasize the fact that coordinated effort between a producer and a supplier improves the supply chain performance. More specifically, regarding supplier performance, previous studies (most of them with an environmental focus) have shown that coordinated effort plays a role on the supplier side. (Klassen and Vachon, 2003) found that the development of joint efforts between the producer and its suppliers motivates changes in the suppliers' plants (i.e.: implementation of pollution prevention systems) to meet environmental requirements.

Additionally, as pointed by (Gold et al., 2009) activities such as suppliers' training should allow improvements in both the supplier and the buyer. Particularly, in the case of the producer's social performance, (Gimenez et al., 2012) empirically showed that the implementation of cooperative activities with suppliers contributes to increase the producer's social reputation. Recently, (Gualandris et al., 2014) found that the adoption of inter-organisational performs helped to improve the sustainability performance of the producer. Similarly, we believe that by working together with suppliers on social issues (e.g., offering training on social aspects or working together to solve deficiencies in the suppliers' health and safety conditions), producers will develop useful knowledge and skills that will serve to improve their own social performance.

Based on these arguments and on the RBV we hypothesize that:

Hypothesis 4. Coordinated effort with suppliers improves the suppliers' social performance

Hypothesis 5. Coordinated effort with suppliers improves the producer's social performance

\subsection{PRODUCER'S AND SUPPLIERS' SOCIAL PERFORMANCE}

Suppliers' performance impacts the competitive dimensions of producers and hence plays a key role on their long-term success (Carter, 2005; Krause et al., 2000). This can also be applied to the sustainability context. In line with these authors we believe that producers employees' satisfaction and well-being (i.e., producer's social performance) will increase as a result of being in a firm that sources from socially-responsible suppliers (i.e., suppliers with high levels of social performance). Employees who feel that can make an impact on social and environmental issues while at work are twice more satisfied with their job than those who don't (Zukin and Szeltner, 2012). In addition, the producer will also be able to improve its social performance through increased social reputation. If the supplier is able to improve the working conditions and compliance with child labor standards and human rights the social reputation of the producer will improve. 
In summary, we have hypothesized the following direct effects. First, we have hypothesized a positive effect between evaluation and coordinated effort (H1). Then, based on empirical evidence we have posited a positive effect between evaluation and both the suppliers' (H2) and producer's (H3) social performance. Similarly, based on the RBV, we have hypothesized a positive effect between coordinated effort and the suppliers' $\left(\mathrm{H}_{4}\right)$ and producer's social performance $\left(\mathrm{H}_{5}\right)$. We also believe that the suppliers' social performance has a positive impact on the producer's social performance (H6). The combination of the above mentioned hypotheses results in a mediated model. This suggests that there might be an indirect effect between social supply management performs (i.e., evaluation and coordinated effort) and the producer's social performance through suppliers' social performance (i.e., mediating variable). In other words, we expect that the suppliers' social performance mediates the relationship between social supply management performs and the producer's social performance. This mediating effect can be explained as follows: once suppliers have achieved a better social performance due to the implementation of social supply management performs, the producer's social performance will increase. The fact that we have hypothesized a direct effect between social supply management performs (i.e., evaluation and coordinated effort) and producer's social performance (i.e., $\mathrm{H}_{3}$ and $\mathrm{H}_{5}$ ) suggests that the suppliers' performance acts as partial mediator rather than a full mediator (Baron and Kenny, 1986). This reasoning leads to the two following hypotheses:

Hypothesis 7. Suppliers' social performance partially mediates the relation- ship between evaluation and the producer's social performance.

Hypothesis 8. Suppliers' social performance partially mediates the relation- ship between collaboration and the producer's social performance.

The combination of the previous hypotheses results in the conceptual model presented in Figure 1.

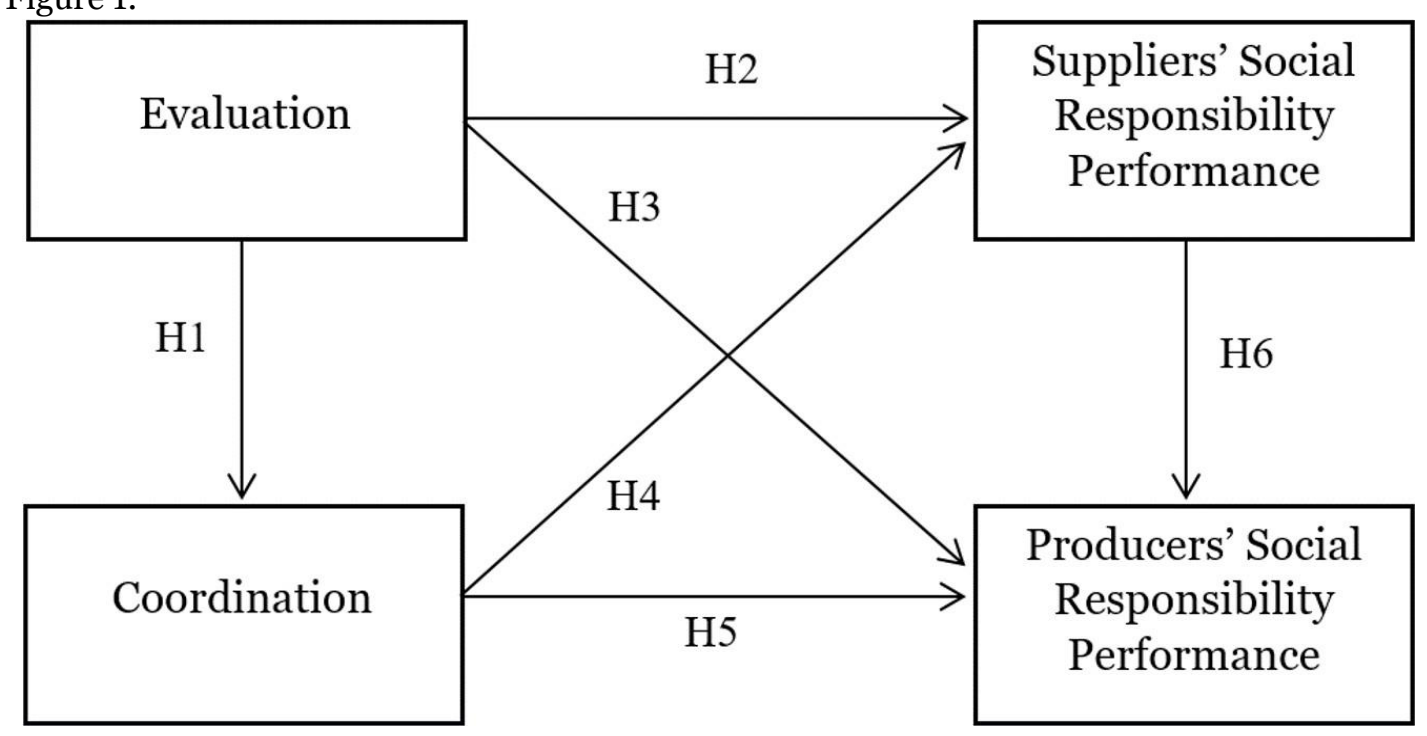

Fig. 1 Conceptual model

\section{METHODOLOGY}

\subsection{QUESTIONNAIRE DESIGN}

The survey instrument employed in this research was designed and developed based on a literature review. A pre-test was carried out with academics in order to check the understanding and clarity of the questions resulting in minor changes with respect to the wording of some items. For each of the studied constructs multiple items were considered which were adapted from previous literature. 
Suppliers evaluation-this construct includes the evaluation of suppliers' in terms of social issues, auditing suppliers with respect to social issues and the provision of feedback to suppliers as a result of their evaluations. This construct and items were adapted from (Krause et al., 2000) and (Large and Thomsen, 2011).

Coordinated effort with suppliers-in the case of coordinated effort, the considered three items entail: visiting suppliers' premises, training suppliers in terms of social issues and the development of joint efforts with them with respect to social sustainability. These items were adapted from Krause et al. (2000) and Vachon and Klassen (2008).

Producer's social performance - producer's social performance items include the use of social indicators, the improvement of the company's social reputation, the reduction of industrial accidents, as well as the improvement of safety and labor conditions. These items were adapted from (Maxwell et al., 2006), (Giovanni, 2012) and (Gimenez et al., 2012). Suppliers' social performance - the suppliers' social performance items are related to the improvement of safety and labor conditions, the employment of child labor and the respect for human rights in the supplier's premises perceived by the producer. These items were developed based on the works of (Awaysheh and Klassen, 2010). All the indicators used were measured by a five-point Likert scale, where higher values indicated higher level of adoption or better performance.

\subsection{SAMPLE AND DATA COLLECTION}

Data from a sample of Vietnam producers' companies was collected between January and April 2019. We used database to extract a list of all Vietnam producers' that had at least 50 employees. After having eliminated those companies that did not meet with the requirement and number of employees' criteria as well as those that did not have complete contact details we were left with a sample of 270 companies. A phone call was made to all of them requesting their participation in the research. In total, we obtained 96 responses. To minimize key-informant bias our first step was to contact each firm by phone and identify the most suitable respondent with respect to the extension of sustainability performs to suppliers (Kumar et al., 1993). Furthermore, the use of different data collection methods (telephone and e-mail) may be a threat to the research. Due to the big difference in size regarding the total number of responses obtained by telephone and e-mail, a sub-sample of 19 responses was randomly selected from the responses of the phone group. Parametric tests were performed for each item involved in the research and no significant differences between phone and e-mail responses were found. Non-response bias could have also been a threat to our research. In that sense, we performed non-response bias tests comparing the demographic data (number of employees and turnover) of respondents and non-respondents. No noticeable pattern among the variables that could indicate the existence of a non-responsebias was found.

\section{DATA ANALYSIS AND RESULTS}

The objective of our research is to explore the relationships among different theoretical constructs (i.e., practices and performance). In particular, our model examines whether the adoption of evaluation and collaborative practices to manage the relationship with suppliers with respect to social issues directly improves both the supplier's and the producer's social performance. To test the hypothesized relationships between the constructs we used non-parametric structural equation modeling via partial least square (PLS) analysis. In PLS, measurement and structural parameters are estimated via an iterative procedure, which combines simple and multiple regressions by traditional ordinary least squares (OLS), thus avoiding any distributional assumption of the observed variables. 
Three reasons made us use the PLS method for our data analysis. First, PLS is an appropriate tool when the research objectives are exploratory in nature (Peng and Lai, 2012). In our case, the relationships we aim to research have seldom been examined in the literature (i.e., the social dimension of sustainability has been scantily studied and the suppliers' performance has been largely neglected). Second, the impossibility to fulfill the set of assumptions of the parametric structural equation modeling technique (based on maximum likelihood estimators) including multivariate normality of data and minimum sample size suggests PLS procedure to be the best approach to the test the hypothesized model. Finally, it is important to highlight that PLS allow us to estimate simultaneously all the hypothesized relationships in our model.

Our PLS analysis entails two stages: the evaluation of the measurement model and the evaluation of the path model. The first stage, measurement evaluation, addresses the valuation of the reflective constructs in terms of internal consistency, individual indicators' reliability, and convergent and discriminant validity. Then, the evaluation of the path model stage covers the estimation and the statistical test of the hypothesized relationships between the constructs. It is important to mention that concerns about OLS estimation were checked using jackknife estimation procedure to compute $95 \%$ bias corrected confidence intervals for every path coefficient.

As already mentioned, in the sustainable supply management literature there is a lack of studies focusing on the social dimension of sustainability. In that sense, a scale that measures social constructs such as social performance or social practices has not been developed (Giovanni, 2012). Therefore, our first step was to conduct an exploratory factor analysis via principal component analysis to define the fundamental constructs underlying our original indicators. After having checked the sample adequacy for the exploratory factor analysis using Kaiser-Meyer-Olkin (KMO) test and Barlett's test of sphericity and having removed one item from the evaluation construct (Eva2) because of cross loading, we obtained a five factor solution which retains $84.24 \%$ of the constructs indicators' total variance.

The resulting five dimensions are labeled as Evaluation (Eva1, Eva3), Coordinated effort (Coor1, Coor2, Coor3), Producer's Social Character (PSCf1, PSCf2), Producer Employees' Satisfaction (PESf1, PESf2), and Suppliers' Social Responsibility Performance (SSRPf1, SSRPf2, SSRPf3).

\begin{tabular}{|c|c|c|c|c|c|c|c|c|}
\hline Representative & Items & Mean & StDev & Loading & $\begin{array}{c}\% \text { of } \\
\text { explained } \\
\text { variance }\end{array}$ & $\begin{array}{c}\text { Alpha } \\
\text { Cronbach }\end{array}$ & $\begin{array}{l}\text { Comp } \\
\text { Reliab }\end{array}$ & AVE \\
\hline \multirow[t]{3}{*}{ Evaluation } & Eva1 & 3.20 & 1.12 & 0.910 & \multirow{3}{*}{$81.24 \%$} & \multirow{3}{*}{0.800} & \multirow{3}{*}{0.90} & \multirow{3}{*}{0.850} \\
\hline & Eva2 & 2.50 & 1.22 & - & & & & \\
\hline & Eva3 & 2.66 & 1.15 & 0.870 & & & & \\
\hline \multirow[t]{3}{*}{ Coordination } & Coor1 & 2.10 & 1.03 & 0.843 & \multirow{3}{*}{$68.11 \%$} & \multirow{3}{*}{0.753} & \multirow{3}{*}{0.77} & \multirow{3}{*}{0.762} \\
\hline & Coor2 & 1.25 & 0.41 & 0.711 & & & & \\
\hline & Coor3 & 2.31 & 1.12 & 0.850 & & & & \\
\hline Producer's Social & PSCf1 & 3.10 & 1.10 & 0.915 & \multirow{2}{*}{$81.40 \%$} & \multirow{2}{*}{0.824} & \multirow{2}{*}{0.91} & \multirow{2}{*}{0.867} \\
\hline Character & PSCf2 & 3.20 & 0.21 & 0.910 & & & & \\
\hline Producer's Empl. & PESf1 & 4.31 & 0.19 & 0.921 & \multirow{2}{*}{$84.32 \%$} & \multirow{2}{*}{0.788} & \multirow{2}{*}{0.89} & \multirow{2}{*}{0.839} \\
\hline Satisfaction & PESf2 & 4.72 & 0.15 & 0.844 & & & & \\
\hline Supplier's Social & SSRPf1 & 2.11 & 0.99 & 0.924 & \multirow{3}{*}{$88.25 \%$} & \multirow{3}{*}{0.900} & \multirow{3}{*}{0.92} & \multirow{3}{*}{0.910} \\
\hline Responsibility & SSRPf2 & 2.31 & 1.21 & 0.903 & & & & \\
\hline Performance & SSRPf3 & 1.99 & 1.01 & 0.913 & & & & \\
\hline \multicolumn{9}{|c|}{$\begin{array}{l}\text { EFA Analysis Adequacy: } \\
\mathrm{KMO}=0.71 \text { (threshold value is } 0.5 \text { ) } \\
\text { Barlett's test--> } \mathrm{X}^{2}=720.370<00\end{array}$} \\
\hline
\end{tabular}

Fig. 2 Descriptive and measurement evaluation (factor loadings and reliability)

The factorial structure of our measured indicators scale reveals five constructs: two that are related to the practices used to extend social issues to suppliers (the independent variables hypothesized in the structural model) and three related to social performance (the dependent variables). Regarding social performance constructs it is important to highlight the fact that three 
constructs were obtained. In our initial model we defined two constructs related to performance: the producer's and the suppliers' social performance (See Figure 1). However, the results of the exploratory factor analysis suggest that the producer's social performance indicators form two different constructs rather than one. These new constructs are defined as follows: one refers to reputation (Producer's Social Character) and the other refers to employees' working conditions (Producer Employees' Satisfaction).

The adequacy of the scales was evaluated analyzing convergent validity, discriminant validity and reliability. Convergent validity is assessed by checking that the item loadings are significant and greater than 0.70 and that the average variance extracted (AVE) of each construct is greater than 0.50 (Peng and Lai, 2012). Results in Fig. 2 show that in our research convergent validity for both the construct and the indicator level is fulfilled. Discriminant validity is assessed by comparing the AVE of each construct and the shared variance between each pair of constructs (Anderson and Gerbing, 1988; Morgan et al., 2007). For the fulfillment of discriminant validity the square root value of AVE should be greater than all of the inter-construct correlations. Fig. 3 provides support for sufficient discriminant validity since the square root of the AVE of each construct is higher than its correlations. Finally, reliability was judged by using both composite reliability and Cronbach's alpha coefficient. Results in Fig. 1 show that all the scales have a value greater than the threshold value of 0.70 and the strictest threshold of 0.8 (Nunnally, 1978; Lindell and Whitney, 2001) for composite reliability. Cronbach's alpha values are also greater than the 0.70 threshold. These results indicate that all constructs are reliable.

\begin{tabular}{|c|c|c|c|c|c|}
\hline & Evaluation & Coordination & $\begin{array}{l}\text { Producer's } \\
\text { Social } \\
\text { Character }\end{array}$ & $\begin{array}{l}\text { Producer's } \\
\text { Empl. } \\
\text { Satisfaction }\end{array}$ & $\begin{array}{l}\text { Supplier's } \\
\text { Social } \\
\text { Responsibility } \\
\text { Performance }\end{array}$ \\
\hline Evaluation & $0.89^{1}$ & & & & \\
\hline Coordination & $0.51^{2}$ & 0.79 & & & \\
\hline $\begin{array}{l}\text { Producer's Social } \\
\text { Character }\end{array}$ & 0.40 & 0.15 & 0.90 & & \\
\hline $\begin{array}{l}\text { Producer's Empl. } \\
\text { Satisfaction }\end{array}$ & 0.15 & 0.11 & 0.32 & 0.91 & \\
\hline $\begin{array}{l}\text { Supplier's Social } \\
\text { Responsibility } \\
\text { Performance }\end{array}$ & 0.21 & 0.31 & 0.29 & 0.11 & 0.92 \\
\hline
\end{tabular}

Fig. 3 Measurement evaluation: discriminant validity

Finally, we checked that common method variance (CMV) is not a threat to the validity of our results. We used both a priori and a posteriori procedure. First, during the questionnaire design the dependent variables were placed after the independent variables in the survey (Podsakoff et al., 2003). This helps to diminish the effects of consistency artifacts. Then, we also checked for the presence of CMV a posteriori by using both the Harmans (Podsakoff et al., 2003) method and the (Lindell and Whitney, 2001) method. The rationale behind the Harmans' single factor method is that if a "substantial amount of common method bias is present, either (a) a single factor will emerge from the factor analysis, or (b) one general factor will account for the majority of the covariance among measures". The results show that five factors emerge and that one single factor accounts only for the $39 \%$ of the variance. Lindell and Whitney's method examines the correlations between a variable that is theoretically unrelated to the constructs under research marker variable) and the studied constructs. High correlations between the marker variable and the studied constructs indicate the presence of CMV. As a marker variable we used a variable from the survey, which was not included in our analysis (i.e., risk of supply). The Pearson correlation coefficients between the marker variable and the studied constructs. The highest value corresponds to Coordinated effort (Pearson $r=-0.13$ ). If we square the Pearson correlation coefficient we get the maximum percentage of variance shared by the marker and the construct $\left(\mathrm{R}^{2}\right)$. CMV would be a threat to the research if $\mathrm{R}^{2}$ shows high values. In our case, $\mathrm{R}^{2}$ equals $2 \%$, which is a low value. These results confirm the absence of CMV. 


\section{MODEL EVALUATION}

The second step in our analysis is the estimation of the path model relationships. Before looking at the results of the direct and indirect path coefficients, it is important to assess the structural model for multi-collinearity issues. Since the estimation of the path coefficients is based on OLS regression, just as in regular multiple regression, the path coefficient might be biased if the estimation involves multi-collinearity between the studied constructs. VIFs between constructs are under the suggested threshold of 5 showing that multi-collinearity is not an issue.

The results of the path model evaluation are shown in Fig. 5. Totest the statistical significance of the model parameters we used the bootstrap procedure (Efron, 1979; Diaconis and Efron, 1983). The procedure entailed the generation of 1000 subsamples of cases with a bootstrap sample size of 96. The estimated values for the path coefficients, which indicate the strength of the direct relationships between constructs, provide full empirical support forthree of the six hypotheses related to direct effects $(\mathrm{H} 1, \mathrm{H} 4, \mathrm{H} 6)$ and partial support for one additional hypotheses $\left(\mathrm{H}_{3}\right)$. Our results show that there is a positive and direct impact from Evaluation to Coordinated effort $(\mathrm{p}=0.001)$, providing support for $\mathrm{H} 1$. This highlights that Evaluation is an antecedent of Coordinated effort.

Evaluation was significantly linked to the Producer's Social Character $(\mathrm{p}=0.001)$ but no support was found for the impact on Producer Employees' Satisfaction ( $\mathrm{p}=0.123)$, providing partial support to $\mathrm{H}_{3}$. This means that by evaluating suppliers, producers can improve their own social reputation but not their employees' satisfaction. In addition, there is also a positive and significant path between Coordinated effort and Suppliers' Social Responsibility Performance $(\mathrm{p}=0.012)$ providing support for $\mathrm{H}_{4}$ and suggesting that the direct involvement of the producer in solving social issues (i.e., coordinated effort with suppliers) results in a higher social performance for the supplier (e.g., better safety and health conditions).

In addition, the direct paths from Evaluation to Suppliers' Social Responsibility Performance $(p=0.220)$ and Coordination to both the Producer's Social Character $(p=0.211)$ and Producer Employees' Satisfaction $(\mathrm{p}=0.220)$ were not significant, providing no evidence to support hypotheses $\mathrm{H}_{2}$ and $\mathrm{H}_{5}$. Finally, there is a positive and direct impact between Suppliers' Social Responsibility Performance and both the Producer's Social Character $(\mathrm{p}=0.003)$ and Producer's Employees' Satisfaction ( $\mathrm{p}=0.05)$. This provides support for H6.

\begin{tabular}{|c|c|c|c|c|c|c|}
\hline & Hypothesis & $\begin{array}{l}\text { Original } \\
\text { sample }\end{array}$ & $\begin{array}{l}\text { Std. } \\
\text { Error }\end{array}$ & Sign. & \multicolumn{2}{|c|}{$\begin{array}{c}95 \% \text { Bias } \\
\text { corrected CI }\end{array}$} \\
\hline H1 & Evaluation $\rightarrow$ Coordination & 0.340 & 0.034 & 0.001 & 0.252 & 0.805 \\
\hline $\mathrm{H} 2$ & Evaluation $\rightarrow$ Supplier's Social Responsibility Performance & 0.050 & $0.055^{2}$ & 0.220 & -0.123 & 0.344 \\
\hline $\mathrm{H}_{3}$ & $\begin{array}{l}\text { Evaluation } \rightarrow \text { Producer's Social Character } \\
\text { Evaluation } \rightarrow \text { Producer's Empl. Satisfaction }\end{array}$ & $\begin{array}{l}0.125 \\
0.024\end{array}$ & $\begin{array}{l}0.0500 \\
0.0600\end{array}$ & $\begin{array}{l}0.001 \\
0.123\end{array}$ & 0.211 & $\begin{array}{l}0.570 \\
0.346\end{array}$ \\
\hline $\mathrm{H}_{4}$ & $\begin{array}{l}\text { Coordination } \rightarrow \text { Supplier's Social Responsibility } \\
\text { Performance }\end{array}$ & 0.150 & 0.0560 & 0.112 & -0.044 & $\begin{array}{l}0.511 \\
0.056\end{array}$ \\
\hline $\mathrm{H}_{5}$ & $\begin{array}{l}\text { Coordination } \rightarrow \text { Producer's Social Character } \\
\text { Coordination } \rightarrow \text { Producer's Empl. Satisfaction }\end{array}$ & $\begin{array}{l}-0.043 \\
-0.055\end{array}$ & $\begin{array}{l}0.0500 \\
0.0660\end{array}$ & $\begin{array}{l}0.211 \\
0.220\end{array}$ & $\begin{array}{r}0.059 \\
-0.142\end{array}$ & $\begin{array}{l}0.110 \\
0.121\end{array}$ \\
\hline H6 & $\begin{array}{l}\text { Supplier's Social Responsibility Performance } \rightarrow \text { Producer's } \\
\text { Social Character } \\
\text { Supplier's Social Responsibility Performance } \rightarrow \text { Producer's } \\
\text { Empl. Satisfaction } \\
\text { ing variables }\end{array}$ & $\begin{array}{l}0.112 \\
0.105\end{array}$ & 0.041 & $\begin{array}{l}0.003 \\
0.05\end{array}$ & $\begin{array}{l}0.040 \\
0.021\end{array}$ & $\begin{array}{l}0.281 \\
0.320\end{array}$ \\
\hline $\begin{array}{l}\text { Interr } \\
\text { Interr }\end{array}$ & $\begin{array}{l}\text { social applying } \rightarrow \text { Producer's Social Character } \\
\text { social applying } \rightarrow \text { Producer's Empl. Satisfaction }\end{array}$ & $\begin{array}{l}0.130 \\
0.115\end{array}$ & $\begin{array}{l}0.042 \\
0.051\end{array}$ & $\begin{array}{l}0.019 \\
0.012\end{array}$ & $\begin{array}{l}0.053 \\
0.023\end{array}$ & $\begin{array}{l}0.290 \\
0.295\end{array}$ \\
\hline
\end{tabular}

Fig. 4 Direct Effects: Path Coefficient Results

As suggested both by (Rungtusanatham et al., 2014) we relied on bootstrapping to test for the mediating role of Suppliers' Social Performance between both performs (i.e., Evaluation and Coordinated effort) and the Producer's Social Responsibility Performance (H7 and H8). The results for the mediating effects results are reported in Fig. 3. In the case of Evaluation, the fact that the relationship between Evaluation and the Suppliers' Social Responsibility Performance (a) is not significant $(\mathrm{p}=0.440$ ) implies the non-existence of a potential mediating role of Suppliers'Social Performance. Thus, providing no support for H7. In the case of Coordinated effort, its 
relationship with Suppliers' Social Performance (a) is significant ( $p=0.022)$. In addition, the relationship between Suppliers' Social Performance and the Producer's Social Character $(\mathrm{p}=0.006)$ and Producer Employees' Satisfaction ( $\mathrm{p}=0.005$ ) (b) are both significant. For this case, the computed 95\% bootstrapped confidence intervals for mediation (ab) show that Suppliers' Social Performance does not mediate the relationship between Coordinated effort on both Producer's Social Reputation ([-0.199:0.324]) and Producer Employees Well-Being ([- 0.155:0.313]). These results do not provide support for $\mathrm{H} 8$.

Firm's size, industry and the producer's level of social internal practices may have an impact on the producer's performance (Gimenez et al., 2012; Klassen, 2001; Zhu et al., 2008). Because of this, prior to the testing of our model, we checked for their relationship with our two main dependent constructs (i.e., Producer's Social Reputation and Producer Employees' Well-Being). For size, we checked for the correlation between the logarithm number of employees and the above mentioned dependent variables. The results in Fig. 4 show that the correlation is nonsignificant. For industry, we employed the Kruskal Wallis non-parametric test (which is also reported in Fig. 4) and no significant relationships were found between these variables. This implies that in our specific sample of Vietnamese manufacturing companies, size and industry are not an issue. Consequently, we did not include them in our model. For the level of internal practices, we also computed the correlation it was significant. Therefore, we included it when testing our model. As shown in the results the relationships between our control variable (i.e., level of internal social practices) has a significant and positive impact on both dimensions of producer's social performance. This means that companies that have implemented internal social practices will have higher social performance. This is in line with previous literature (Giovanni, 2012; Gimenez et al., 2012; KRAUSE et al., 2009).

Finally, the coefficient of determination $\left(R^{2}\right)$ for each dependent construct indicates the proportion of the dependent construct's variance that is explained by its predictors. The $R^{2}$ for the Producer's Social Reputation, Producer Employees Well-Being and Suppliers' Social Performance are $32.5 \%, 12.9 \%$ and $13.4 \%$ respectively and statistically different from zero $(\mathrm{p}<.001)$.

\section{DISCUSSION AND CONCLUSION}

\subsection{DISCUSSION}

Our results show that when studying the impact of supplier evaluation and coordinated effort with suppliers, there is the need to distinguish between the producer's and the suppliers' social performance. Infact, each performimpactsdifferentlyon each performancedimension. We believe our findings contribute to the development of a social performance scale by suggesting two key constructs to measure it: one related to the suppliers' social performance and two related to the producer's social performance. The following ideas can be derived from these findings.

First, when studying the adoption of evaluation and collaborative applies to obtain a sustainable supply chain, not only the performance of the producer should be considered (Giovanni, 2012; Gimenez et al., 2012) but also the performance of the supplier. Both the producer and the supplier are essential entities in the relationship. Studying only the performance of the producer will provide a partial view on the effectiveness of these applies. For instance, by only considering the producer's performance one can assume that evaluation is effective on achieving social performance improvements.

Second, when measuring the producer's performance our findings suggest that the distinction between producer's reputation and producer's employees' well-being is needed. As an additional analysis, we have computed the partial contribution of both Evaluation and Coordinated effort on the $\mathrm{R}^{2}$ of Producer Employees Satisfaction $\left(\mathrm{R}^{2}=5.2 \%\right)$ and Producer's Social Character $\left(\mathrm{R}^{2}=20.2 \%\right)$. In our study, by differentiating between both producer's performance dimensions, 
we have been able to denote that sustainable supply management applies (i.e., evaluation and coordinated effort) do not really contribute to explain the Producer Employees' Satisfaction in contrast to the Producer's Social Character. The Producer Employees' Satisfaction is measured as improvements in health and safety conditions as well as a reduction in the number of accidents in the producer's premises. Thus, it makes sense that only $6.2 \%$ of the variance of the producer employees' satisfaction is explained by the use of these applies. These apply denote an external dimension (i.e., practices applied to suppliers) and therefore will contribute to improve the employees' satisfaction to a limited extent.

Social performance should therefore, be measured through a combination of measures related with employees' satisfaction and firm's reputation. This paper contributes with respect to the work of (Gualandris et al., 2014) in the fact that our findings suggest that both types of measures (i.e., employees' satisfaction and firm's reputation) should be considered as two separate constructs, as sustainable supply management practices may impact them differently. In fact, as shown in our results, evaluation has a positive impact on the producer's social reputation while no effect on the producer employees' satisfaction.

Our results also show that supplier evaluation and coordinated effort with suppliers have a different effect for the producer's and for the suppliers' social performance: while assessing suppliers helps to improve the producer's social reputation, coordinating with them contributes to improve the suppliers' social performance.

These findings can be considered original since, to the best of our knowledge, there are no prior studies that have considered the impact of these applies on these different performance dimensions. We will discuss these results in detail in the following lines. Suppliers' monitoring and evaluation (i.e., evaluation) help to improve the producer's social reputation. That is, by assessing their suppliers, producers are able to improve their social image. Overall, taken together, both results (i.e., impact of evaluation on producer's reputation and no impact of evaluation on producer's employees satisfaction) reveal the importance of considering both social reputation and employees' well-being as two separate constructs. This implies that auditing and monitoring suppliers on social issues (e.g., working conditions or child employment) does not lead to direct improvements in their facilities. The fact that assessing suppliers does not lead to improvements in the social performance of the supplier can also be explained following Jamison and Murdoch's (2004) description of audits: audits can only take a snapshot of what is happening in a supplier business (e.g., poor labor conditions) but they do not explore why this is happening or how the situation can be improved. These social issues at the suppliers' premises identified by the implementation of evaluation practices are improved (i.e., leading to higher suppliers' social performance) when collaborative practices are implemented. Our results also show that coordinated effort has a positive and direct influence on the suppliers' social performance, as suggested by the RBV. As we have already mentioned, coordinated effort has a direct impact on the suppliers' social performance, meaning that the provision of training and the direct involvement of the producer helps the supplier to improve their working conditions.

Finally, it has to be pointed out that the supplier's social performance does not mediate the relationship between supply management practices and the producer's performance. In our model, this means that (1) evaluation has an impact on producer's reputation regardless of the performance improvements achieved in the suppliers' premises; and (2) coordinated effort improves the supplier's performance although this improvement does not lead to improvements in the producer's social performance. Summarizing, the main message is that both supplier evaluation and coordinated effort with suppliers are needed to achieve a socially responsible supply chain. Whereas evaluation contributes to improve the social reputation of the producer; coordinated effort helps to improve the social performance of the supplier. 


\subsection{CONCLUSION}

The objective of our research was to dissect the viability of sustainable supply management performance (i.e., evaluation and coordinated effort) on achieving a sustainability supply chain. We studied the impact that each of these practices have on both the producer's and the suppliers' social performances. Our outcomes recommend that while evaluating providers adds to improve the suppliers' social performance (e.g., helps to improve their working conditions).

Furthermore, we have likewise contributed to related research by concentrating on a dismissed area of sustainability: the social measurement. In that sense, we accept that future research should include the three recognized constructs when considering social performance in supply chains.

Vietnam companies ready to improve their social image can actualize provider evaluation practices. The monitoring and evaluation of suppliers assist with improving the producer's social notoriety. However, if companies intend to accomplish a sustainability supply chain (i.e., they need their suppliers to be sustainable) they need to coordinate with them. Suppliers' social performance only improves with the adoption of coordinates effort practices (e.g., training suppliers, visiting their premises...).

\section{References}

Anderson JC, Gerbing DW (1988) Structural equation modeling in practice: A review and recommended two-step approach. Psychological Bulletin 103(3):411-423, DOI 10.1037/00332909.103.3.411, URL https://dx.doi.org/10.1037/0033-2909.103.3.411

Ashby A, Leat M, Hudson-Smith M (2012) Making connections: a review of supply chain management and sustainability literature. Supply Chain Management: An International Journal 17(5):497-516, DOI 10.1108/13598541211258573, URL https://dx.doi.org/10.1108/ 13598541211258573

Awaysheh A, Klassen RD (2010) The impact of supply chain structure on the use of supplier socially responsible practices. International Journal of Operations \& Production Management 30(12):1246-1268, DOI 10.1108/01443571011094253, URL https://dx.doi.org/10.1108/ 01443571011094253

Barney JB (1991) Firm resources and sustained competitive advantage. Journal of Management 17(1):99-120

Baron RM, Kenny DA (1986) The moderator-mediator variable distinction in social psychological research: Conceptual, strategic, and statistical considerations. Journal of Personality and Social Psychology 51(6):1173-1182, DOI 10.1037/0022-3514.51.6.1173, URL https://dx.doi.org/10. 1037/0022-3514.51.6.1173

Carter CR (2005) Purchasing social responsibility and firm performance: the key mediating roles of organizational learning and supplier performance. International Journal of Physical Distribution \& Logistics Management 35(3):177-194

Carter CR, Jennings MM (2004) THE ROLE OF PURCHASING IN CORPORATE SOCIAL RESPONSIBILITY: A STRUCTURAL EQUATION ANALYSIS. Journal of Business Logistics 25(1):145-186, DOI 10.1002/j.2158-1592.2004.tboo173.x, URL https://dx.doi.org/10. 1002/j.2158-1592.2004.tboo173.x

Carter CR, Rogers DS (2008) A framework of sustainable supply chain management: mov- ing toward new theory. International Journal of Physical Distribution \& Logistics Man- agement 38(5):360-387, DOI 10.1108/09600030810882816, URL https://dx.doi.org/10.1108/ 09600030810882816

de Castro GM, López JEN, Sáez PL (2006) Business and Social Reputation: Exploring the Concept and Main Dimensions of Corporate Reputation. Journal of Business Ethics 63(4):361370, DOI 10.1007/s10551-005-3244-z, URLhttps://dx.doi.org/10.1007/s10551-005-3244-z 
Corbett CJ, Klassen RD (2006) Extending the Horizons: Environmental Excellence as Key to Improving Operations. Manufacturing \& Service Operations Management 8(1):5-22, DOI 10.1287/msom.1060.0095, URL https://dx.doi.org/10.1287/msom.1060.0095

Diaconis P, Efron B (1983) Computer-Intensive Methods in Statistics. Scientific American 248(5):116-130, DOI 10.1038/scientificamerican0583-116, URL https://dx.doi.org/10.1038/ scientificamericano583-116

Efron B (1979) Bootstrap Methods: Another Look at the Jackknife. The Annals of Statistics 7(1):1-26, DOI 10.1214/aos/1176344552, URL https://dx.doi.org/10.1214/aos/1176344552 Elkington J (1994) Towards the Sustainable Corporation: Win-Win-Win Business Strategies for Sustainable Development. California Management Review 36(2):90-100, DOI 10.2307/ 41165746, URL https://dx.doi.org/10.2307/41165746

Foerstl K, Reuter C, Hartmann E, Blome C (2010) Managing supplier sustainability risks in a dynamically changing environment-Sustainable supplier management in the chemical industry. Journal of Purchasing and Supply Management 16(2):118-130, DOI 10.1016/j. pursup.2010.03.011, URL https://dx.doi.org/10.1016/j.pursup.2010.03.011

Gavronski I, et al. (2011) A resource-based view of green supply management. Transportation Research Part E: Logistics and Transportation Review 47(6):872-885, DOI 10.1016/j.tre.2011. 05.018, URL https://dx.doi.org/10.1016/j.tre.2011.05.018

Gimenez C, Sierra V (2013) Sustainable Supply Chains: Governance Mechanisms to Greening Suppliers. Journal of Business Ethics 116(1):189-203, DOI 10.1007/s10551-012-1458-4, URL https://dx.doi.org/10.1007/s10551-012-1458-4

Gimenez C, Sierra V, Rodon J (2012) Sustainable operations: Their impact on the triple bottom line. International Journal of Production Economics 140(1):149-159, DOI 10.1016/j.ijpe.2012. 01.035, URL https://dx.doi.org/10.1016/j.ijpe.2012.01.035

Giovanni PD (2012)

Gold S, Seuring S, Beske P (2009) Sustainable supply chain management and inter-organizational resources: a literature review. Corporate Social Responsibility and Environmental Management 17:n/a-n/a, DOI 10.1002/csr.207, URL https://dx.doi.org/10.1002/csr.207

Golini R, Longoni A, Cagliano R (2014) Developing sustainability in global manufacturing networks: The role of site competence on sustainability performance. International Journal of Production Economics 147:448-459, DOI 10.1016/j.ijpe.2013.06.010, URL https://dx.doi.org/10.1016/j.ijpe.2013.06.010

Green KW, Zelbst PJ, Bhadauria VS, Meacham J (2012) Do environmental collaboration and monitoring enhance organizational performance? DOI 10.1108/02635571211204254, URL https://dx.doi.org/10.1108/02635571211204254

Gualandris J, Kalchschmidt M (2014) Customer pressure and innovativeness: Their role in sustainable supply chain management. Journal of Purchasing and Supply Management 20(2):92103, DOI 10.1016/j.pursup.2014.03.001, URL https://dx.doi.org/10.1016/j.pursup.2014.03.001

Gualandris J, Golini R, Kalchschmidt M (2014) Do supply management and global sourcing matter for firm sustainability performance? Supply Chain Management: An International Journal 19(3):258-274, DOI 10.1108/scm-11-2013-0430, URL https://dx.doi.org/10.1108/scm-112013-0430

Handfield R, Sroufe R, Walton S (2005) Integrating environmental management and supply chain strategies. Business Strategy and the Environment 14(1):1-19, DOI 10.1002/bse.422, URL https://dx.doi.org/10.1002/bse.422

Hartmann J, Moeller S (2014) Chain liability in multitier supply chains? Responsibility attributions for unsustainable supplier behavior. Journal of Operations Management 32(5):281-294, DOI 10.1016/j.jom.2014.01.005, URL https://dx.doi.org/10.1016/j.jom.2014.01.005

Hollos D, Blome C, Foerstl K (2012) Does sustainable supplier co-operation affect performance? Examining implications for the triple bottom line. International Journal of Production Research 50(11):2968-2986, DOI 10.1080/00207543.2011.582184, URL https://dx.doi.org/10. 1080/00207543.2011.582184

Ilo (2014) URL http://www.ilo.org/global/topics/working-conditions/lang--en/index.htm 
Klassen RD, Vereecke A, Kleindorfer PR, Singhal K, Wassenhove LV (2005) Social issues in supply chains: capabilities link responsibility, risk (opportunity), and performance. International Journal of Production Economics 140(1):103-115

Koplin J, Seuring S, Mesterharm M (2007) Incorporating sustainability into supply management in the automotive industry - the case of the Volkswagen AG. Journal of Cleaner Production 15(11-12):1053-1062, DOI 10.1016/j.jclepro.2006.05.024, URL https://dx.doi.org/10.1016/j. jclepro.2006.05.024

Krause DR, Scannell TV, Calantone RJ (2000) A Structural Analysis of the Effectiveness of Buying Firms' Strategies to Improve Supplier Performance. Decision Sciences 31(1):33-55, DOI 10.1111/j.1540-5915.2000.tbo0923.x, URL https://dx.doi.org/10.1111/j.1540-5915.2000. tboog23.x

KRAUSE DR, et al. (2009) SPECIAL TOPIC FORUM ON SUSTAINABLE SUPPLY CHAIN MANAGEMENT: INTRODUCTION AND REFLECTIONS ON THE ROLE OF PURCHASING MANAGEMENT. Journal of Supply Chain Management 45(4):18-25, DOI 10.1111/j.1745-493x.2009.03173.x, URL https://dx.doi.org/10.1111/j.1745-493x.2009.03173.x

Kumar N, Stern LW, Anderson JA (1993) Conducting inter-organizational research using key informants. Academy of Management Journal 36(6):1633-1651

Large RO, Thomsen CG (2011) Drivers of green supply management performance: Evidence from Germany. Journal of Purchasing and Supply Management 17(3):176-184, DOI 10.1016/ j.pursup.2011.04.006, URL https://dx.doi.org/10.1016/j.pursup.2011.04.006

Lee SY, Klassen RD (2008) Drivers and Enablers That Foster Environmental Management Capabilities in Small- and Medium-Sized Suppliers in Supply Chains. DOI 10.3401/poms. 1080.0063, URL https://dx.doi.org/10.3401/poms.1080.0063

Leppelt T, Foerstl K, Reuter C, Hartmann E (2013) Sustainability management beyond organizational boundaries-sustainable supplier relationship management in the chemical industry. Journal of Cleaner Production 56(1):94-102, DOI 10.1016/j.jclepro.2011.10.011, URL https://dx.doi.org/10.1016/j.jclepro.2011.10.011

Lindell MK, Whitney DJ (2001) Accounting for common method variance in cross-sectional research designs. Journal of Applied Psychology 86(1):114-121, DOI 10.1037/0021-9010.86.1. 114, URL https://dx.doi.org/10.1037/0021-9010.86.1.114

Maxwell D, Sheate W, van der Vorst R (2006) Functional and systems aspects of the sustainable product and service development approach for industry. Journal of Cleaner Produc- tion 14(17):1466-1479, DOI 10.1016/j.jclepro.2006.01.028, URL https://dx.doi.org/10.1016/ j.jclepro.2006.01.028

Mckenzie S (2004) Social sustainability: towards some definitions. Magill

Min H, Galle WP (1997) Green Purchasing Strategies: Trends and Implications. International Journal of Purchasing and Materials Management 33(2):10-17, DOI 10.1111/j.1745-493x.1997. tboo026.x, URL https://dx.doi.org/10.1111/j.1745-493x.1997.tbooo26.x

Morgan NA, Kaleka A, Gooner RA (2007) Focal supplier opportunism in supermarket retailer category management. Journal of Operations Management 25(2):512-527, DOI 10.1016/j.jom. 2006.05.006, URL https://dx.doi.org/10.1016/j.jom.2006.05.006

Nunnally JC (1978) Psychometric theory. McGraw-Hill, New York

Pagell M, Gobeli D (2009) How Plant Managers' Experiences and Attitudes Toward Sustainability Relate to Operational Performance. DOI 10.1111/j.1937-5956.2009.01050.x, URL https://dx.doi.org/10.1111/j.1937-5956.2009.01050.x

PAGELL M, WU Z (2009) BUILDING A MORE COMPLETE THEORY OF SUSTAINABLE SUPPLY CHAIN MANAGEMENT USING CASE STUDIES OF 10 EXEMPLARS. Journal of Supply Chain Management 45(2):37-56, DOI 10.1111/j.1745-493x.2009.03162.x, URL https: //dx.doi.org/10.1111/j.1745-493x.2009.03162.x

Podsakoff PM, MacKenzie SB, Lee JY, Podsakoff NP (2003) Common method biases in behavioral research: A critical review of the literature and recommended remedies. Journal of Applied Psychology 88(5):879-903, DOI 10.1037/o021-9010.88.5.879, URL https://dx.doi. org/10.1037/0021-9010.88.5.879 
Prahinski C, Benton WC (2004) Supplier evaluations: communication strategies to improve supplier performance. Journal of Operations Management 22(1):39-62, DOI 10.1016/j.jom. 2003.12.005, URL https://dx.doi.org/10.1016/j.jom.2003.12.005

Pullman M, Maloni M, Carter C (2009) Food for Thought: Motivations to Adopt Sustainability Practices and Perceived Outcomes. Journal of Supply Chain Management 45(4):38-54

Rungtusanatham M, Miller JW, Boyer KK (2014) Theorizing, testing, and concluding for mediation in SCM research: Tutorial and procedural recommendations. Journal of Operations Management 32(3):99-113, DOI 10.1016/j.jom.2014.01.002, URL https://dx.doi.org/10.1016/ j.jom.2014.01.002

Seuring S, Müller M (2008) From a literature review to a conceptual framework for sustainable supply chain management. Journal of Cleaner Production 16(15):1699-1710, DOI 10.1016/j. jclepro.2008.04.020, URL https://dx.doi.org/10.1016/j.jclepro.2008.04.020

Seuring S, etal.(2013)Sustainability managementbeyond corporateboundaries: from stakeholders to performance. Journal of Cleaner Production 56:1-6, DOI 10.1016/j.jclepro.2012.11.033, URL https://dx.doi.org/10.1016/j.jclepro.2012.11.033

Simpson D, Power D (2005)

Spence L, Bourlakis M (2009) The evolution from corporate social responsibility to supply chain responsibility: the case of Waitrose. Supply Chain Management: An International Journal 14(4):291-302, DOI 10.1108/13598540910970126, URL https://dx.doi.org/10.1108/ 13598540910970126

Vachon S, Klassen RD (2006) Extending green practices across the supply chain: the impact of upstream and downstream integration. International Journal of Operations and Production Management 26:795-821

Vachon S, Klassen RD (2008) Environmental management and manufacturing performance: The role of collaboration in the supply chain. International Journal of Production Economics 111(2):299-315, DOI 10.1016/j.ijpe.2006.11.030, URL https://dx.doi.org/10.1016/j.ijpe.2006. 11.030

Walton SV, Handfield RB, Melnyk SA (1998) The Green Supply Chain: Integrating Suppliers into Environmental Management Processes. International Journal of Purchasing and Materials Management 34(1):2-11, DOI 10.1111/j.1745-493x.1998.tboo042.x, URL https://dx.doi.org/ 10.1111/j.1745-493x.1998.tbooo42.x

Williamson OE (1975) Markets and hierarchies: analysis and antitrust implications. Free Press, New York

Williamson OE (1981) The Economics of Organization: The Transaction Cost Approach. American Journal of Sociology 87(3):548-577, DOI 10.1086/227496, URL https://dx.doi.org/10. $1086 / 227496$

Williamson OE (1991) Strategizing, economizing, and economic organization. Strategic Management Journal 12:75-94

Zhu Q, Sarkis J (2007) The moderating effects of institutional pressures on emergent green supply chain practices and performance. International Journal of Production Re- search 45(18-19):4333-4355, DOI 10.1080/00207540701440345, URL https://dx.doi.org/10. 1080/00207540701440345

Zhu Q, Sarkis J, hung Lai K, Geng Y (2008) The role of organizational size in the adoption of green supply chain management practices in China. Corporate Social Responsibility and Environmental Management 15(6):322-337, DOI 10.1002/csr.173, URL https://dx.doi.org/10. $1002 /$ csr. 173 